MIRAN ŠTUHEC: ŽIVE BESEDE IN PRODORNE MISLI. Antologija slovenske esejistike prve polovice 20. stoletja. Ljubljana, Študentska založba. 2013. (Zbrika Beletrina).

Najnovejše delo rednega profesorja doktorja Mirana Štuheca nam na prefinjen, zvedav in premišljen način prinaša vpogled $\mathrm{v}$ esejistiko prve polovice 20 . stoletja, ki je izšla osem let po izidu Aristokracije jezika in duha, antologijskega pregleda esejistike druge polovice 20. stoletja. Sedaj imamo v dobri meri zaokrožen pregled v slovensko esejistiko prejšnjega stoletja; bila je vse prej kot nekonkurenčna: $\mathrm{z}$ odličnimi jezikovnimi manevri, duhovnimi potenciali in ustvarjalnimi zamislimi, se je lahko brez večjih težav postavila ob bok takrat sodobnim evropskim esejističnim subjektom.

Miran Štuhec je ugleden doktor znanosti in profesor za slovensko književnost na Oddelku za slovanske jezike in književnosti Filozofske fakultete Univerze v Mariboru. Njegovo širše raziskovalno področje je slovenska proza 19. in 20. stoletja, drugo polje raziskav pa slovenska miselna proza, še posebej esejistika. Po literarnozgodovinski sintezi povojne slovenske esejistike je njegova raziskovalna pozornost namenjena esejistiki do leta 1950. Izhajajoč iz zagrebške naratološke šole je v poznih osemdesetih letih uveljavil pristop, ki je bil $\mathrm{v}$ slovenskem prostoru dokaj nov, v okviru programske skupine Slovensko jezikoslovje, književnost in poučevanje slovenščine je do sedaj $\mathrm{z}$ naratološke perspektive obravnaval nekatera ključna pripovedna dela slovenske književnosti ter izbrane razprave slovenskega zgodovinopisja. Rezultati, objavljeni v monografijah in domačih ter tujih revijah, prinašajo spoznanja o tipologiji pripovedovalca, o fokalizacijskem kodu, o aktantskem vprašanju ter o problematiki avtorjevega glasu. Osrednji interes dr. Štuheca ni literarna teorija, je pa z njo tesno povezan, zato so raziskave pogosto aplikacija določenih teoremov, njihovo dopolnjevanje in prilagajanje karakteristikam slovenske književnosti. Izdal je več samostojnih znanstvenih monografij: Rad prebiram misli, ne živim jih pa rad. Poetika pripovedne proze Pavleta Zidarja (Ljubljana: Rokus, 1996), Naratologija. Med teorijo in prakso (Ljubljana: Studentska založba, 2000), Slovenska esejistika prve polovice dvajsetega stoletja (Ljubljana: Slovenska matica, 2003), Aristokracija jezika in duha. Antologija slovenske esejistike po drugi svetovni vojni. (Ljubljana: Študentska založba, 2005), Slovenska esejistika od začetkov do leta 1950 (Ljubljana: Študentska založba, 2010), Književne teme (Maribor: Založba Pivec, 2013), svoje delo pa je predstavljal doma in v tujini (Ljubljana, Bled, Nova Gorica, Moskva, St. Petersburg, Gradec, Zagreb, Krakow, Sombotel). Bil je vodja slovenskega dela bilateralnega sporazuma Hrvaška in slovenska književnost kot sosednji književnosti ter član komisije za ocenjevanje mednarodnih raziskovalnih projektov. Pohvali pa se lahko tudi z vrsto gostujočih predavanj, ki so se odvijala na več domačih in tujih univerzah, kot so Ljubljana, Zagreb, Brno, Praga, Bielsko Biała, St. Petersburg.

V pričujoči knjigi je Štuhec izbral štirinajst avtorjev in prav toliko esejev, ki so si po njegovem mnenju, po jezikovnih in slogovnih ter problemskih in idejnih določnicah zaslužili tovrsten izbor. Z njim je predstavil najvidnejše predstavnike slovenske esejistike prve polovice 20. stoletja, ki so takrat razmišljali o problemih slovenstva in 
Slovencev, hkrati pa so iskali navdihe $\mathrm{v}$ drugih pokrajinah ter $\mathrm{v}$ mislih, podobah in duhu tujih kniževnikov ter filozofov. Eseji so razvrščeni po letnicah objave - od najstarejšega, Cankarjevih Podob iz sanj, do najmlajšega, Komu zvoni Juša Kozaka. V presečišču esejev $\mathrm{v}$ antologiji prevladuje tematika umetnika, umetnosti, umetnikovega statusa in njegove lastne progresije skozi domovinska očala, perspektive, ki upošteva narodnostni kontekst, kar lahko vidimo v Vidmarjevem dialogu med ljubiteljem in kritikom v eseju Pogovor o Arhimedovi točki, v Cankarjevih Podobah iz sanj, Župančičevem Ritmu in metrumu, Prijateljevem Domovina, glej, umetnik, Jarčevem eseju Umetnost in življenje. France Vodnik je razmišljal o sodobnosti v umetnosti, o vrednotah, ki jih Slovenci ob tem izgubljamo in o konzervatizmu - ta nam oži poglede na svet. O umetnosti je prav tako esejiziral Ivo Brnčič. Opisoval je umetniško progresivnost, vrednost umetnosti, ki jo je ta vedno sama določala preko čuta za objektivno resničnost. Izidor Cankar je $\mathrm{v}$ antologiji predstavljen $\mathrm{z}$ esejem Uvod k XIII. knjigi Zbranega dela Ivana Cankarja, kjer je evociral Cankarja $\mathrm{z}$ več življenjsko-ustvarjalnih vidikov. Anton Ocvirk je razmišljal o metafiziki Leona Šestova, o razvrednotenju vseh vrednot, Bratko Kreft je prepoznaven po ukvarjanju z Miroslavom Krležo, medtem ko je Vladimir Bartol poudaril ponotranjeno dojemanje Freudovega dela in lika. Za razliko od vseh zgoraj naštetih avtorjev sodita eseja Edvarda Kocbeka in Božidarja Borka med redke, ki se že v izhodišču umakneta iz domovine. Kocbek je o domovini razmišljal, jo primerjal in orisoval skozi povsem oddaljeno Španijo (Premišljevanje o Španiji), Borko je reflektiral Prago, kjer je v njeni odlični arhitek- turi in dognanem urbanizmu doživel veličastne refleksije drugih evropskih mest. Dr. Štuhec jima je ob bok postavil Juša Kozaka z esejem Komu zvoni?, v katerem ta piše o o Hemingwayu kot o kronistu vojne.

Knjiga Žive in prodorne misli je opremljena z izčrpno študijo in beležkami o avtorjih. Avtor je v slednjih poudaril najpomembnejše biografske in bibliografske podatke o posameznih esejistih, v spremni študiji pa je utemeljil merila izbora, opozoril na kulturnozgodovinske okoliščine v prvi polovici 20 . stoletja, izpostavil problemske sklope takratne slovenske esejistike, se ustavil ob svetovnonazorskih vprašanjih in jezikovnih ter notranjeslogovnih značilnostih korpusa. Poudaril je, da so v knjigo uvrščeni eseji, ki na različne načine izražajo čas, v katerem so nastali. Tukaj se je avtor navezal na okoliščine, ki so bile za Slovence obravnavanega obdobja izjemno pestre. Nova vprašanja, ki jih odkriva Štuhečeva antolgija, postanejo izrazitejša ob obeh vojnah. Še močneje pa pridejo do izraza, ko se se liberalni in klerikalni politični struji pridružil marksisti. Vse tri skupine so pritegnile del intelektualne sfere, ki je začela že s koncem 19. in v začetku 20. stoletja odpirati oziroma izostrovati poglede na narod, na problem slovenstva, jezika in politike. Ob teh nazorskih pogledih so izbrani esejisti odstirali tudi vprašanje umetnosti in človeških vrednot. V antologiji je prepoznavno, da si esejisti zastavljajo vprašanja o svobodi, umetnosti, umetnikovem položaju, subjektivni in objektivni resnici, narodni samostojnosti, kulturi, zgodovini in politiki. Avtor nam je z izborom prikazal, kaj je bilo za esejiste $\mathrm{v}$ tedanjem času pomembno, $v$ katere smeri se je širila esejistična refleksija in kaj esejističnozgodovinskega je ostalo pomembno do 
današnjih dni. Kajti tudi sami si ob branju izbranih esejev lahko skozi historično perspektivo ponotranjimo dogodke iz našega vsakdana.

Namen rednega profesorja dr. Štuheca je $\mathrm{z}$ antološkim izborom dosežen, saj ponuja celovit vpogled $\mathrm{v}$ do sedaj še neobdelan opus. $\mathrm{S}$ tem in s svojo zgodovino predvojnega eseja je postavil osnovo nadaljnjim raziskavam, ki se bodo verjetno osredotočale na ozka področja slogovnih značilnosti, filozofskih podlag ali morebitno delo esejistk. Kot mlada slovenistka se sprašujem, kje $\mathrm{v}$ antologiji odmeva ženski glas. Zanimivo bi bilo prebrati tudi esejistične refleksije Zofke Kvedrove, Lili Novy ali Milene Mohorič in ugledati sliko slovenske esejistike prve polovice 20. stoletja še s perspektiv raziskovalk.

Vita Zgoznik vita.zgoznik@gmail.com

\section{JOŽICA ČEH STEGER: EKSPRESIONISTIČNA STILNA PARADIGMA V KRATKI PRIPOVEDNI PROZI 1914-1923.}

Maribor: Filozofska fakulteta, Mednarodna založba Oddelka za slovanske jezike in književnosti, 2010 (Zora, 69).

Z monografijo Jožice Čeh Steger je slovenska literarna veda pridobila izjemno poglobljeno študijo o ekspresionistični kratki prozi na Slovenskem. Njeno raziskovalno delo je osredinjeno na preučevanje metaforike, izhajajoče iz interakcijske teorije metafore, podrob- neje predstavljene že v monografiji $\mathrm{Me}$ taforika $v$ Cankarjevi kratki pripovedni prozi (2001). Z razčlenitvijo metaforike v izbranem opusu slovenske kratke pripovedne proze je razširila seznam sekundarnih virov o ekspresionizmu (Janko Kos, Lado Kralj, Boris Paternu, Helga Glušič, Franc Zadravec, Gregor Kocijan, Bojana Stojanović Pantović idr.) in $\mathrm{z}$ naslonitvijo na raziskave $\mathrm{o}$ nemškem ekspresionizmu z oblikovanjem lastnega pristopa opozorila na temeljne značilnosti pripovedne proze v obdobju 1914-1923. Obsežen pregled kratkoproznih virov zgodnjega obdobja slovenske ekspresionistične pripovedne proze prinaša spoznanja do sedaj še neraziskanega področja - predvsem metaforike.

Monografija prinaša sistematičen prikaz ekspresionistične stilne paradigme skozi prizmo metaforičnih pojavov skrbno izbranega avtorskega in literarnega opusa. V uvodnem delu nas avtorica podrobneje seznani s slovenskimi raziskovalci ekspresionizma in natančneje analizira ter poda uvid $\mathrm{v}$ značilnosti nemškega ekspresionizma, opozori na možne vplive ob zgodovinsko prelomnem trenutku, ko so bili slovenski pisatelji tudi vojaki in so občutili prvo svetovno vojno $v$ luči grozljivih razsežnostih. Literarna besedila razkrivajo ekspresionistične topose (vojna, strah, razčlovečenje idr.), značilnosti tematsko-idejne ali stilne ravni, hkrati pa avtorica opozori na iztekajoče se smeri in stile moderne (Stanko Majcen, Marija Kmet).

V pregledni monografiji predgovoru in uvodu sledi sistematična obravnava posameznih literatov kratke pripovedne proze. Skoraj pričakovano začenja s Cankarjevimi Podobami iz sanj, ki se, tako avtorica, s strukturnim modelom sanj, tematiko vojne, $\mathrm{z}$ nelepo in 